\title{
YOGA PRACTICE HAS MINOR INFLUENCE ON RESPIRATORY FUNCTION AT REST IN MEN AND WOMEN
}

\author{
Kristina Zaičenkovienė ${ }^{1}$, Arvydas Stasiulis ${ }^{1}$, Roma Aleksandravičiene் ${ }^{1,2}$, \\ Loreta Stasiulevičien $\dot{e}^{1}$ \\ Lithuanian Sports University ${ }^{l}$, Kaunas, Lithuania \\ Aleksandras Stulginskis University', Kaunas, Lithuania
}

\begin{abstract}
Research background and hypothesis. Hatha yoga breathing has the potential of training the respiratory system in such a way that it helps an individual to cope with the respiratory demand (Ray et al., 2011).

Research aim was to compare pulmonary function variables between physically inactive subjects and the ones practicing hatha yoga and to evaluate changes after 6 months of yoga practice in the latter group.

Research methods. Pulmonary function was measured by means of the gas analyser "Oxycon Mobile" (Germany) before and after 6 months of yoga training in men $(\mathrm{n}=11)($ age $-30.8(7.06)$, BMI $-25.6(2.6))$ and women $(\mathrm{n}=11)$ (age - $28.9(6.86)$, BMI - $22.5(2.3)$ ) practicing yoga and control subjects $(\mathrm{n}=22)$ of similar age. Measurements included forced vital capacity (FVC), forced expiration volume in one second (FEV(1)), forced inspiratory volume in one second FIV1, vital capacity (VC), peak expiratory flow (PEF), forced expiratory flow rate (FEF (25-75)\%), forced inspiratory flow at $50 \%$ of the vital capacity (FIF50\%), maximum voluntary ventilation (MVV), vital capacity (VC MAX), peak inspiratory flow (PIF), etc.

Research results. Pulmonary function measures FEF 75/85 (L/s) $(\mathrm{p}=0.036)$, total volume inspired FVC IN (L) $(p=0.014)$, FIV1 (L) $(p=0.045)$ were significantly higher in the group practicing yoga than in the control group of women, and VC MAX (\%) (p = 0.018), FEV $1(\%)(p=0.041)$, FEF $25(\mathrm{~L} / \mathrm{s})(\mathrm{p}=0.017)$, FVC IN $(\mathrm{L})(\mathrm{p}=0.002)$ in men practicing yoga, than in men not practicing yoga. They also demonstrated higher values of MVV $(\mathrm{L} / \mathrm{min})$ $(p=0.068)$ and FVC (L) $(p=0.050)$. After 6 months of practicing yoga we found higher FEF $50(L / s)(p=0.003)$, FEF $50 \%(L / s)(p=0.003)$ in women's group and $\operatorname{VCMAX}(\%)(\mathrm{p}=0.028)$ in men's group. We also found a tendency of the increase of VCMAX (L) (p = 0.053), PIF (L/s) (p = 0.051), FVC IN (L) (p = 0.061), FIVI (L) $(\mathrm{p}=0.064)$ indexes in men and PIF $(\mathrm{L} / \mathrm{s})(\mathrm{p}=0.072), \mathrm{FVC}$ IN $(\mathrm{L})(\mathrm{p}=0.076)$ in women.

Discussion and conclusions. Yoga practice appeared to have minor influence on respiratory function at rest in men and women of middle age. Additional studies examining various yoga practices are warranted to gain a more comprehensive understanding of the effects of yoga techniques on pulmonary functions.
\end{abstract}

Keywords: pulmonary function at rest, yoga training, yoga breathing.

\section{INTRODUCTION}

Y oga breathing (pranayama) is an important part of health and spiritual practices (Brown, Gerbarg, 2009). Yoga practices are low intensity exercises within lactate threshold, physical performance improvement is possible owing to both better economy of breathing and to the improvement in cardiovascular reserve (Ray et al., 2011). Yoga induces long-term changes in respiratory function and control (Bernardi et al., 2007). Long-term yoga practice improves the depth of breathing and alters chemoreceptive sensitivity (Stanescu et al., 1981; Bernardi et al., 2001). Yoga improves pulmonary function, as measured by maximum inspiratory pressure, maximum expiratory pressure, maximum voluntary ventilation, forced vital capacity, forced expiratory volume in one second, and peak expiratory flow rate (Abel et al., 2012). 


\section{RESEARCH METHODS}

Participants. Forty four healthy men $(\mathrm{n}=22)$ and women $(n=22)$ volunteered to participate in our study. Twenty two subjects were physically inactive: 11 of them men were not practicing yoga (YNM) and 11 - not practicing women (YNW) and the other 22 subjects were practicing yoga for one year: 11 men (YPM) and 11 women (YPW). Statistically significant differences in body mass indexes (BMI) between control and yoga practicing subjects were not found.

Body composition analysis. The height of the subjects was taken using the Height Measuring Scale. The body weight of each subject was measured using electronic scale "Tanita Body Composition Analyzer TBF-300" (Japan). When the subjects stood on a special platform, the device recorded their body mass $(\mathrm{kg})$, body mass index $\left(\mathrm{kg} / \mathrm{m}^{2}\right)$, fat body mass $(\%, \mathrm{~kg})$ and lean body mass $(\%, \mathrm{~kg})$.

Spirometry. Aiming at establishing gas metabolism indices, we applied the portable gas analyzer "Oxycon Mobile" (Germany) to register respiration indices for each subject: forced vital capacity (FVC), forced expiration volume in one second (FEV(1)), forced inspiratory volume in one second FIV1 vital capacity (VC), peak expiratory flow (PEF), forced expiratory flow rate (FEF (2575) \%), forced inspiratory flow at $50 \%$ of the vital capacity (FIF 50\%), maximum voluntary ventilation (MVV), vital capacity (VC MAX), peak inspiratory flow (PIF), etc. Prior to each testing the respiratory gas analyzer was calibrated according to the automatic calibration method proposed by Jaeger.

Table 1. Parameters of pulmonary function at rest in women in the control group and in those who were practicing yoga

\begin{tabular}{|c|c|c|c|c|c|}
\hline $\begin{array}{c}\text { Parameters of } \\
\text { pulmonary function }\end{array}$ & $\begin{array}{c}\text { Women's } \\
\text { control group }\end{array}$ & YPW & \begin{tabular}{|c|} 
p-level \\
between groups
\end{tabular} & $\begin{array}{c}\text { YPW after } 6 \text { months } \\
\text { of yoga practice }\end{array}$ & \begin{tabular}{|c|}
$\begin{array}{c}\text { p-level after } 6 \text { months } \\
\text { of yoga practice }\end{array}$ \\
\end{tabular} \\
\hline VC MAX, L & $4.08(0.60)$ & $4.56(1.22)$ & 0.673 & $3.83(0.54)$ & 0.145 \\
\hline VC MAX, \% & $105.21(10.39)$ & $116.02(28,11)$ & 0.336 & $100.59(11.82)$ & 0.152 \\
\hline FEV 1, L & $3.53(0.45)$ & $3.74(0.51)$ & 0.516 & $3.52(0.45)$ & 0.367 \\
\hline FEV 1, \% & $106.13(10.17)$ & $111.57(10.49)$ & 0.291 & $108.01(11.10)$ & 0.496 \\
\hline FEV $1, \%$ & $96.30(5.07)$ & $97.00(2.56)$ & 0.826 & $95.16(4.1)$ & 0.376 \\
\hline MVV, L/min & $126.10(23.21)$ & $130.54(9.07)$ & 0.503 & $134.21(14.80)$ & 0.718 \\
\hline MVV, L/min & $106.25(18.74)$ & $110.39(10.34)$ & 0.376 & $115.69(12.57)$ & 0.584 \\
\hline FVC, L & $3.68(0.48)$ & $3.77(0.58)$ & 0.717 & $3.703(0.49)$ & 0.755 \\
\hline FVC, L & $96.48(10.92)$ & $100.3(10.64)$ & 0.448 & 98.95 (11.02) & 0.766 \\
\hline $\mathrm{PEF}, \mathrm{L} / \mathrm{s}$ & $6.62(1.39)$ & $7.25(1.52)$ & 0.309 & $7.29(0.93)$ & 0.944 \\
\hline $\mathrm{PEF}, \mathrm{L} / \mathrm{s}$ & $90.66(16.78)$ & $99.15(20.85)$ & 0.244 & $92.68(29.52)$ & 0.525 \\
\hline $\mathrm{PIF}, \mathrm{L} / \mathrm{s}$ & $5.48(1.14)$ & $6.13(1.50)$ & 0.491 & $6.82(1.35)$ & 0.072 \\
\hline FEF $25, \mathrm{~L} / \mathrm{s}$ & $6.36(1.39$ & $6.55(2.00)$ & 0.813 & $6.62(0.85)$ & 0.932 \\
\hline FEF $25, \mathrm{~L} / \mathrm{s}$ & $100.67(20.30)$ & $97.87(42.34)$ & 0.874 & $106.21(11.63)$ & 0.620 \\
\hline FEF $50, \mathrm{~L} / \mathrm{s}$ & $4.87(0.99)$ & $5.79(0.93)$ & 0.058 & $4.89(0.88)$ & 0.003 \\
\hline FEF $50 \%, \mathrm{~L} / \mathrm{s}$ & $106.3(20.7)$ & $123.97(21.22)$ & 0.091 & $108.96(17.73)$ & 0.003 \\
\hline FEF $75, \mathrm{~L} / \mathrm{s}$ & $2.48(0.80)$ & $2.96(1.14)$ & 0.331 & $2.66(1.01)$ & 0.495 \\
\hline FEF $75, \mathrm{~L} / \mathrm{s}$ & $114.96(35.13)$ & $127.76(45.08)$ & 0.520 & $128.01(47.10)$ & 0.851 \\
\hline FEF $75 / 85, \mathrm{~L} / \mathrm{s}$ & $1.87(0.56)$ & $2.56(0.79)$ & 0.068 & $2.11(0.89)$ & 0.288 \\
\hline FEF 75/85, L/s & $131.36(31.50)$ & $181.26(51.13)$ & 0.036 & $159.07(61.53)$ & 0.588 \\
\hline FVC IN, L & $3.45(0.45)$ & $4.29(1.41)$ & 0.144 & $3.67(0.64)$ & 0.265 \\
\hline FVC IN, L & $89.37(9.71)$ & $118.39(30.71)$ & 0.014 & $96.28(14.81)$ & 0.076 \\
\hline FIV1, L & $3.42(0.44)$ & $4.05(0.69)$ & 0.045 & $3.646(0.64)$ & 0.150 \\
\hline FIV1, FVC, \% & $98.91(0.66)$ & $93.86(9.88)$ & 0.130 & $99.44(0.31)$ & 0.12 \\
\hline BMI & $21.73(2.26)$ & $22.59(2.37)$ & 0.446 & $22.6(2,00)$ & 0.074 \\
\hline
\end{tabular}

Note. YPW - women practicing yoga. 
Organization of the research. The studies were conducted in the Laboratory of Sports Physiology at the Department of Applied Biology and Rehabilitation. The subjects were familiarized with the research and they signed informed consent to participate in the study. The pulmonary parameters were tested under the same conditions at rest, after establishing their BMI. The subjects not practicing yoga were tested once and those who were practicing yoga - twice: they were repeatedly tested after 6 months of yoga practice.

Mathematical statistics. Results were analysed applying the following methods of mathematical statistics: calculating and presenting (in figures and tables) means and standard deviations; comparing the means of the samples using one-way ANOVA. For the reliability of statistical hypothesis, the level of statistical significance was set at $(\mathrm{p}<0.05)$.
The data were processed using computer programs: "LAB Manager", "Microsoft Excel", Statistica for Windows.

\section{RESEARCH RESULTS}

Pulmonary function measures FEF 75/85 (L/s) $(\mathrm{p}=0.036)$, total volume inspired FVC IN (L) $(p=0.014)$, FIV1 $(L)(p=0.045)$ were significantly higher in yoga practicing women than in those in the control group, and VC MAX (\%) $(\mathrm{p}=0.018)$, FEV $1(\%)(\mathrm{p}=0.041)$, FEF $25(\mathrm{~L} / \mathrm{s})$ $(p=0.017)$, FVC IN (L) $(p=0.002)$ in men practicing yoga, than in men not practicing yoga. They also demonstrated higher values of MVV (L/ $\min )(p=0.068)$ and FVC $(L)(p=0.050)$.

After 6 months of practicing yoga, we found higher FEF $50(\mathrm{~L} / \mathrm{s})(\mathrm{p}=0.003)$, FEF $50 \%(\mathrm{~L} / \mathrm{s})$

Table 2. Parameters of pulmonary function of men in the control group and in yoga practice group

\begin{tabular}{|c|c|c|c|c|c|}
\hline $\begin{array}{c}\text { Parameters of } \\
\text { pulmonary function }\end{array}$ & NPJM & PJM & $\begin{array}{c}\text { p-level } \\
\text { between groups }\end{array}$ & $\begin{array}{c}\text { PJM after } 6 \text { months } \\
\text { of yoga practice }\end{array}$ & $\begin{array}{c}\text { p-level after } 6 \text { months } \\
\text { of yoga practice }\end{array}$ \\
\hline VC MAX, L & $5.50(0.67)$ & $5.79(0.76)$ & 0.691 & $6.04(0.68)$ & 0.053 \\
\hline VC MAX, \% & $111.08(16.67)$ & $131.39(12.64)$ & 0.018 & $136.34(12.84)$ & 0.028 \\
\hline FEV 1, L & $4.72(0.47)$ & $4.83(0.55)$ & 0.895 & $4.87(0.43)$ & 0.279 \\
\hline FEV 1, \% & $115.69(14.02)$ & $129.9(14.29)$ & 0.041 & $130.85(12.04)$ & 0.513 \\
\hline FEV 1, \% & $94.38(6.35)$ & $92.61(7.48)$ & 0.442 & $91.028(5.75)$ & 0.750 \\
\hline $\mathrm{MVV}, \mathrm{L} / \mathrm{min}$ & $193.81(36.60)$ & $201.68(26.61)$ & 0.643 & $200.36(23.91)$ & 0.939 \\
\hline $\mathrm{MVV}, \mathrm{L} / \mathrm{min}$ & $137.31(28.44)$ & $160.3(22.54)$ & 0.068 & $158.71(19.16)$ & 0.748 \\
\hline FVC, L & $5.04(0.64)$ & $5.25(0.68)$ & 0.565 & $5.368(0.50)$ & 0.368 \\
\hline FVC, L & $104.65(10.4)$ & $122.32(15.20)$ & 0.005 & $125.1(14.87)$ & 0.489 \\
\hline $\mathrm{PEF}, \mathrm{L} / \mathrm{s}$ & $9.81(1.48)$ & $10.30(2.62)$ & 0.591 & $10.57(0.99)$ & 0.797 \\
\hline $\mathrm{PEF}, \mathrm{L} / \mathrm{s}$ & $110.21(22.74)$ & $132.26(36.35)$ & 0.133 & $132.97(15.45)$ & 0.814 \\
\hline $\mathrm{PIF}, \mathrm{L} / \mathrm{s}$ & $8.84(2.34)$ & $8.13(1.60)$ & 0.433 & $9.20(1.11)$ & 0.051 \\
\hline FEF $25, \mathrm{~L} / \mathrm{s}$ & $8.59(1.16)$ & $9.46(1.76)$ & 0.184 & $9.87(0.84)$ & 0.514 \\
\hline FEF $25, \mathrm{~L} / \mathrm{s}$ & $112.31(20.09)$ & $141.32(27.55)$ & 0.017 & $147.25(17.88)$ & 0.567 \\
\hline FEF $50, \mathrm{~L} / \mathrm{s}$ & $6.44(1.10)$ & $6.45(1.18)$ & 0.873 & $6.35(1.03)$ & 0.821 \\
\hline FEF $50 \%, \mathrm{~L} / \mathrm{s}$ & $135.74(24.74)$ & $124.5(27.5)$ & 0.477 & $132.78(23.04)$ & 0.754 \\
\hline FEF 75, L/s & $2.81(10.79)$ & $2.89(1.12)$ & 0.702 & $2.26(1.31)$ & 0.265 \\
\hline FEF $75, \mathrm{~L} / \mathrm{s}$ & $129.91(34.78)$ & $120.55(52.96)$ & 0.850 & $103.37(55.13)$ & 0.201 \\
\hline $\mathrm{FEF} 75 / 85, \mathrm{~L} / \mathrm{s}$ & $2.079(0.69)$ & $2.36(1.06)$ & 0.537 & $1.63(1.07)$ & 0.407 \\
\hline FEF $75 / 85, \mathrm{~L} / \mathrm{s}$ & $148.06(43.44)$ & $158.6(75.16)$ & 0.735 & $118.95(68.66)$ & 0.391 \\
\hline FVC IN, L & $4.77(0.60)$ & $5.22(0.71)$ & 0.202 & $5.51(0.57)$ & 0.061 \\
\hline FVC IN, L & 96.05 (11.92) & $118.51(15.22)$ & 0.002 & $125.43(16.07)$ & 0.095 \\
\hline FIV1, L & $4.68(0.60)$ & $5.05(0.72)$ & 0.337 & $5.335(0.44)$ & 0.064 \\
\hline FIV1, FVC, \% & $98.3(4.13)$ & $97.14(7.37)$ & 0.572 & $97.15(4.88)$ & 0.828 \\
\hline BMI & $24.34(1.80)$ & $25.62(2.70)$ & 0.135 & $25.7(2.38)$ & 0.415 \\
\hline
\end{tabular}

Note. YPM - men practicing yoga. 
$(\mathrm{p}=0.003)$ in women group and VCMAX $(\%)$ $(p=0.028)$ in men. We also found a tendency of an increase of VCMAX (L) $(\mathrm{p}=0.053)$, PIF $(\mathrm{L} / \mathrm{s})$ $(p=0.051)$, FVC IN $(L)(p=0.061)$, FIVI $(L)$ $(\mathrm{p}=0.064)$ indexes in men and PIF $(\mathrm{L} / \mathrm{s})$ $(\mathrm{p}=0.072)$, FVC IN (L) $(\mathrm{p}=0.076)$ in women.

\section{DISCUSSION}

In our research men and women practicing Yoga demonstrated higher pulmonary function indices of FEF 75/85, FVC IN, FIV1 in PYW and VC $\operatorname{MAX}(\%)(\mathrm{p}=0.018), \operatorname{FEV} 1(\%)(\mathrm{p}=0.041)$, FEF 25, FVC IN in PYM, than the ones in the control group. YPM also demonstrated higher values of FVC than those in the control group, although we estimated only some differences and tendencies of the increase in pulmonary function indexes during Yoga practice. After 6 months of yoga practice we found higher FEF 50, FEF 50\%, in women's group and VCMAX (\%) in men's group. We observed a tendency of increase of VCMAX, PIF, FVC IN, FI VI indexes in men and PIF, FVC IN in women.

Yoga training results closely indicated the reduction of sympathetic reactivity and improvement in the pulmonary ventilation by means of relaxation of voluntary inspiratory and expiratory muscles (Khanam et al., 1996). S. Singh and his colleagues (2012) found statistically significant improvement $(p<0.001)$ in forced vital capacity $(F V C)$, forced expiratory volume in the 1st sec (FEV1), peak expiratory flow rate (PEFR), maximum voluntary ventilation (MVV) and slow vital capacity (SVC) in patients of bronchial asthma before and after yoga intervention of 2 months. The responses of Alternate Nostril Breathing Pranayama on some cardio-respiratory functions were investigated in healthy young adults. The subjects performed ANB exercise (15 minutes in the morning every day) for four weeks. Cardio-respiratory parameters were recorded before and after a 4-week training period. A significant increment in Peak expiratory flow rate (PEFR L/min) and Pulse pressure (PP) was noted. Although Systolic blood pressure (SBP) decreased insignificantly, the decrease in pulse rate $(\mathrm{PR})$, respiratory rates (RR), diastolic blood pressure (DBP) were significant.

A. N. Abel and colleagues (2012) concluded that pulmonary function appeared to improve with a minimum of 10 weeks of regular yoga practice, and the magnitude of this improvement was related to fitness level and/or the length of time the subjects spent practicing pranayama (i. e. breathing exercises). In other words, greater improvements in pulmonary function were more likely to be seen in less-fit individuals and/or those that engaged in longer periods of pranayama.

Respiratory parameters at rest and during graded exercise test in endurance athletes, sprinters and physically active persons were studied by A. Stasiulis and his colleagues (2009). In their research they concluded that respiratory function at rest was not different between subjects, whereas endurance athletes demonstrated higher relative ventilation and higher $\mathrm{BF}$ during incremental running test. C. Rong and colleagues (2008) observed that lung function measurements correlated with the indicators of sport, age, gender, height, and weight in various athletes. The lung capacity of swimmers was greater than that of other athletes. Small airway dysfunction was observed in some swimmers and endurance athletes. They observed an association between systemic anaphylaxis and small airway dysfunction after prolonged regular training, particularly following swimming and endurance training. S. Singh and colleagues (2012) suggested that pranayama and yoga breathing and stretching postures were used to increase respiratory stamina, relax the chest muscles, expand the lungs, raise energy levels, and calm the body.

\section{CONCLUSIONS AND PERSPECTIVES}

Yoga practice seems, to have minor influence on respiratory function at rest in men and women of middle age. Additional studies examining various yoga practices are warranted to gain a more comprehensive understanding of the effects of yoga techniques on pulmonary functions.

\section{REFERENCES}

Abel, A. N., Lloyd, L. K., Williams, J. S. (2012). The effects of regular yoga practice on pulmonary function in healthy individuals: A literature review. Journal of Alternative and Complementary Medicine.

Bernardi, L., Passino, C., Spadacini, G. et al. (2007). Reduced hypoxic ventilatory response with preserved blood oxygenation in yoga trainees and Himalayan Buddhist monks at altitude: Evidence of a different adaptive strategy? European Journal of Applied Physiology, 99 (5), 511-518.

Bernardi, L., Sleight, P., Bandinelli, G. et al. (2001). Effect of rosary prayer and yoga mantras on autonomic cardiovascular rhythms: Comparative study. British 
Medical Journal (Clinical research ed.), 323 (7327), 1446-1449.

Brown, R. P., Gerbarg, P. L. (2009). Yoga breathing, meditation, and longevity. Annals of the New York Academy of Sciences, 1172, 54-62.

Khanam, A. A., Sachdeva, U., Guleria, R., Deepak, K. K. (1996). Study of pulmonary and autonomic functions of asthma patients after yoga training. Indian Journal of Physiology and Pharmacology, 40 (4), 318-324.

Ray, U. S., Pathak, A., Tomer, O. S. (2011). Hatha yoga practices: Energy expenditure, respiratory changes and intensity of exercise. Evidence Based Complementary Alternative Medicine.

Rong, C., Bei, H., Yun, M., Yuzhu, W., Mingwu, Z. (2008). Lung function and cytokine levels in professional athletes. Journal of Asthma, 45 (4), 343-348.
Singh, S., Soni, R., Singh, K. P., Tandon, O. P. (2012). Effect of yoga practices on pulmonary function tests including transfer factor of lung for carbon monoxide (TLCO) in asthma patients. Indian Journal of Physiology and Pharmacology, 56 (1), 63-68.

Stanescu, D. C., Nemery, B., Veriter, C., Marechal, C. (1981). Pattern of breathing and ventilatory response to $\mathrm{CO}_{2}$ in subjects practicing hatha yoga. Journal of Applied Physiology, Respiratory, Environmental and Exercise Physiology, 51 (6), 1625-1629.

Stasiulis, A., Kilikevičius, A., Dubininkaitè, L., Venckūnas, T., Raubaite, S. (2009). Fiziškai aktyvių asmenų, greičio ir ištvermės šakų sportininkų kvėpavimo rodikliai ramybès metu ir nuosekliai didinant krūvị. Ugdymas. Küno kultūra. Sportas, 2 (73), 92-98.

\title{
JOGOS PRATYBOS SILPNAI VEIKIA VIDUTINIO AMŽIAUS MOTERŲ IR VYRŲ KVĖPAVIMO RODIKLIUS RAMYBĖJE
}

\author{
Kristina Zaičenkoviene் ${ }^{1}$, Arvydas Stasiulis ${ }^{1}$, Roma Aleksandravičiene் $\dot{e}^{1,2}$, \\ Loreta Stasiulevičien $\dot{e}^{1}$ \\ Lietuvos sporto universitetas ${ }^{1}$, Kaunas, Lietuva \\ Aleksandro Stulginskio universitetas ${ }^{2}$, Kaunas, Lietuva
}

\section{SANTRAUKA}

Tyrimo pagrindimas ir hipotezé: daugeliu studiju irodyta teigiama jogos nauda žmogaus sveikatai. Jogos kvėpavimo technika gali pagerinti plaučiu funkciją ramybeje.

Tikslas - palyginti nesportuojančiu asmenu ir praktikuojančiu Hatha jogą kvėpavimo funkcijos rodiklius ramybejje ir įvertinti jų pokyčius po šešių mėnesių jogos pratybų.

Metodai. Norint ịvertinti vyrų $(n=11$; amžius - 30,8 $( \pm 7,06)$ m.; KMI - 25,6 $( \pm 2,6))$, moterų $(n=11$; amžius $28,9( \pm 6,86)$ m., KMI - 22,5 $( \pm 2,3))$, praktikuojančiu jogą, ir kontrolinės tokio pat amžiaus grupės asmenų $(\mathrm{n}=22)$ plaučiu funkcinius rodiklius ramybejje buvo naudotas nešiojamas dujų analizatorius „Oxycon Mobile“ (Jaeger, Vokietija).

Rezultatai. Kvėpavimo funkcijos rodikliai, tokie kaip forsuoto iškvėpimo greitis iškvėpus 75/85\% tūrio $(\mathrm{L} / \mathrm{s} ; \mathrm{p}=0,036)$, forsuoto ịkvėpimo tūris $(\mathrm{L} ; \mathrm{p}=0,014)$, forsuoto ịkvèpimo tūris procentais per $1 \mathrm{~s}(\mathrm{~L} ; \mathrm{p}=0,045)$ joga praktikuojančių moteru grupejje buvo statistiškai reikšmingai didesni nei kontrolinès grupės. Praktikuojančių jogą vyrų maksimalusis gyvybinis plaučių tūris procentais $(\mathrm{p}=0,018)$, forsuoto iškvèpimo tūris procentais per pirmą sekundę ( $\mathrm{L} ; \mathrm{p}=0,041)$, forsuoto iškvėpimo greitis iškvėpus $25 \%$ tūrio $(\mathrm{L} / \mathrm{s} ; \mathrm{p}=0,017)$, forsuoto įkvèpimo tūrio $(\mathrm{L} ; \mathrm{p}=0,002)$ rodikliai buvo didesni už nepraktikuojančių jogos vyrų rodiklius. Po šešių mėnesių jogos pratybų buvo nustatytas didesnis moterų forsuoto iškvėpimo greitis iškvėpus $50 \%$ tūrio $(\mathrm{L} / \mathrm{s} ; \mathrm{p}=0,003)$ ir maksimaliojo gyvybinio plaučių tūrio $(\% ; p=0,028)$ rodikliai vyrų grupeje. Taip pat buvo pastebimos vyrų maksimaliosios gyvybinès plaučių talpos $(\mathrm{L} ; \mathrm{p}=0,053)$, maksimaliojo įkvèpimo greičio $(\mathrm{L} / \mathrm{s} ; \mathrm{p}=0,051)$, forsuoto ịkèpimo tūrio $(\mathrm{L} ; \mathrm{p}=0,061)$, forsuoto ịkvejpimo tūrio per $1 \mathrm{~s}(\mathrm{~L} ; \mathrm{p}=0,064)$ ir moterų maksimaliojo įkvépimo greičio $(\mathrm{L} / \mathrm{s} ; \mathrm{p}=0,072)$ bei forsuoto ¡̇kèpimo tūrio $(\mathrm{L} ; \mathrm{p}=0,076)$ rodiklių didèjimo tendencijos.

Aptarimas ir išvados. Jogos pratybos gali tik silpnai paveikti vidutinio amžiaus vyrų ir moterų kvėpavimo rodiklius ramybėje. Reikalingos papildomos studijos, kurios padètų geriau îvertinti jogos pratybų poveiki plaučių funkcijoms.

Raktažodžiai: plaučių ventiliacija ramybėje, jogos pratybos, jogos kvėpavimas.

Gauta 2013 m. sausio 9 d.

Received on January 9, 2013

Priimta 2013 m. kovo $8 \mathrm{~d}$.

Accepted on March 8, 2013
Corresponding author Kristina Zaičenkovienė

Lithuanian Sports University

Sporto str. 6, LT-44221 Kaunas

Lithuania

Tel +370 37302639

E-mail kristina.zaicenkoviene@1su.lt 